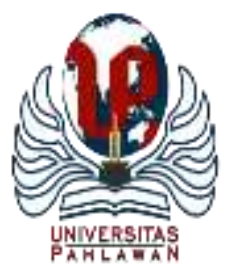

Edukatif : Jurnal Ilmu Pendidikan Volume 3 Nomor 6 Tahun 2021 Halm 4134 - 4144

EDUKATIF: JURNAL ILMU PENDIDIKAN

Research \& Learning in Education

https://edukatif.org/index.php/edukatif/index

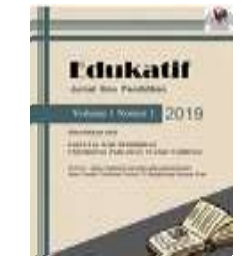

\title{
Pendidikan Masa Pandemik Covid 19: Implementasi Konsep Tri Pusat Pendidikan Ki Hajar Dewantara
}

\author{
Muhlil Musolin $^{1 凶}$, Khoirun Nisa,2 \\ STAI An Nawawi Purworejo, Indonesia ${ }^{1,2}$ \\ E-mail: $\underline{\text { mmuhlil@gmail.com }}^{1}$, $\underline{\text { irunicer@gmail.com }}^{2}$
}

\begin{abstract}
Abstrak
Mewabahnya virus corona atau covid 19 di dunia termasuk Indonesia mengakibatkan pemerintah mengeluarkan kebijakan PSBB yang diantaranya peliburan sekolahmaka kegiatan belajar mengajar dilakukan secara daring dalam rangka pencegahan penyebaran Corona Virus Disease (COVID-19). Oleh karena itu penelitian ini akan membahas tentang implementasi konsep tri pusat pendidikan Ki Hajar Dewantara di masa pandemic covid 19.Hasil Penelitian menunjukkan Implementasi dari konsep tri pusat pendidikan Ki Hajar Dewantara dalam pendidikan masa pandemic covid 19 dilihat dari peran para pihak yaitu: Peran Keluarga: Pendidikan di masa pandemic covid 19 menyebabhkan mahasiswa dan siswa lebih banyak berada dirumah sehingga dapat mengimplementasikan konsep tri pusat pendidikan Ki Hajar Dewantara untuk mendidik budi pekerti dan laku sosial. Peran Sekolah, masa pandemic covid 19 sekolah melaksanakan pendidikan secara online maka sekolah yang konsep tri pusat pendidikan Ki Hajar Dewantara bahwa sekolah sebagai balai wiyata bertugas mencerdaskan cipta, rasa, dan karsa secara seimbang dalam pendidikan masa pandemic covid 19 tidak terwujud dengan baik. Peran masyarakat untuk melakukan penguasaan diri dalam pembentukan watak atau karakter dalam konsep tri pusat pendidikan Ki Hajar Dewantara pada masa pandemic covid 19 dapat terlaksana dengan baik.
\end{abstract}

Kata Kunci: Pandemik Covid 19, Implementasi, Tri Pusat Pendidikan.

\begin{abstract}
The outbreak of coronavirus or covid 19 in the world, including Indonesia, has resulted in the government issuing PSBB policies, including school safeguards, so teaching and learning activities are carried out online to prevent the spread of Corona Virus Disease (COVID-19). Therefore this study will discuss the implementation of the concept of the tri education center Ki Hajar Dewantara during the pandemic covid 19. The results of the study show that the implementation of the Ki Hajar Dewantara tri education center concept in pandemic covid 19 education was seen from the role of the parties, namely: Family Role: Education in the pandemic covid 19 caused more students and students to be at home so that they could implement the tri education center concept Ki Hajar Dewantara to educate manners and social behavior. The Role of Schools in the pandemic Covid 19, council schools carry out education online, so the concept tri education center Ki Hajar Dewantara that schools as centers have to educate the creation, balance, and intention in education in the pandemic covid 19 did not materialize properly. The role of the community to exercise self-control in the formation of character or character in the concept of the tri-center of the Ki Hajar Dewantara education during the pandemic covid 19 periods can be well implemented.
\end{abstract}

Keywords: Pandemic Covid 19, Implementation, Tri Education Center.

Copyright (c) 2021 Muhlil Musolin, Khoirun Nisa'

$\square$ Corresponding author:

Email : mmuhlil@gmail.com

DOI $\quad$ : https://doi.org/10.31004/edukatif.v3i6.1316

ISSN 2656-8063 (Media Cetak)

ISSN 2656-8071 (Media Online)

Edukatif : Jurnal Ilmu Pendidikan Vol 3 No 6 Tahun 2021 p-ISSN 2656-8063 e-ISSN 2656-8071 
4135 Pendidikan Masa Pandemik Covid 19: Implementasi Konsep Tri Pusat Pendidikan Ki Hajar Dewantara - Muhlil Musolin, Khoirun Nisa'

DOI: https://doi.org/10.31004/edukatif.v3i6.1316

\section{PENDAHULUAN}

Diawal tahun 2020 dunia sedang dihebohkan dengan adanya virus corona. Virus Corona atau severe acute respiratory syndrome coronavirus2 (SARS-CoV-2) adalah virus yang menyerang sistem pernapasan. Penyakit karena infeksi virus ini disebut COVID-19. Virus Corona bisa menyebabkan gangguan ringan pada sistem pernapasan, infeksi paru-paru yang berat, hingga kematian. Virus corona bermula dari sebuah pasar makanan laut Huanan di Kota WuhanProvinsi HubeiChina pada bulan Desember 2019kemudian dengan cepat menyebar keseluruh penjuru dunia sehingga World Health Organization (WHO) menyatakan bahwa Virus Corona sebagai pandemi.

Indonesia pertama kali mengkonfirmasi kasus COVID-19 pada bulan Maret tahun 2020.Saat itu, Presiden Joko Widodo mengumumkan ada dua orang Indonesia positif terjangkit virus Corona yakni perempuan berusia 31 tahun dan ibu berusia 64 tahun.Indonesia kemudian menyatakan bahwa Covid-19 sebagai bencana nonalam berupa wabah penyakit yang wajib dilakukan upaya penanggulangan sehingga tidak terjadi peningkatan kasus.Dalam rangka upaya penanggulangan dilakukan penyelenggaraan kekarantinaan kesehatan sebagaimana telah diatur di dalam Undang-Undang No. 6 Tahun 2018 tentang Kekarantinaan Kesehatan. Spesifik untuk penanggulangan Covid-19 pada tanggal 31 Maret 2020 pemerintah telah menetapkan 3 peraturan terkait sebagai bentuk penanggulangan terhadap pandemi tersebut yaitu Keputusan Presiden Nomor 11 Tahun 2020 tentang Penetapan Kedaruratan Kesehatan Masyarakat Corona Virus Disease 2019 (Covid-19) (“Kepres No. 11/2020”), Peraturan Pemerintah Nomor 21 Tahun 2020 tentang Pembatasan Sosial Berskala Besar Dalam Rangka Percepatan Penanganan Corona Virus Disease 2019 (Covid-19) ("PP No. 21/2020") dan Peraturan Pemerintah Pengganti Undang-Undang Nomor 1 Tahun 2020 tentang Kebijakan Keuangan Negara dan Stabilitas Sistem Keuangan Untuk Penanganan Pandemi Corona Virus Disease 2019 (Covid-19) dan/atau Dalam Rangka Menghadapi Ancaman yang Membahayakan Perekonomian Nasional dan/atau Stabilitas Sistem Keuangan ("Perpu No. 1/2020").

Peraturan pemerintah berupa Pembatasan Sosial Berskala Besar Dalam Rangka Percepatan Penanganan Corona Virus Disease 2019 (Covid-19) melalui PP No. 21/2020 dilakukan sebagai upaya mengurangi interaksi banyak orang yang dapat memberi akses pada penyebaran virus corona. Pembatasan Sosial Berskala Besar paling sedikit meliputi peliburan sekolah dan tempat kerja, pembatasan kegiatan keagamaan; dan/atau Pembatasan kegiatan di tempat atau fasilitas umum.

Penyebaran virus corona ini pada awalnya sangat berdampak pada dunia ekonomi yang mulai lesu, tetapi kini dampaknya dirasakan juga oleh dunia pendidikan. Kebijakan yang diambil oleh banyak negara termasuk Indonesia dengan meliburkan seluruh aktivitas pendidikan, membuat pemerintah dan lembaga terkait harus menghadirkan alternatif proses pendidikan bagi peserta didik maupun mahasiswa yang tidak bisa melaksanakan proses pendidikan pada lembaga pendidikan. Kebijakan di bidang pendidikan yang diambil oleh pemerintah terkait kasus COVID 19 yaitu : pembelajaran daring untuk anak sekolah, kuliah daring, ujian nasional 2020 ditiadakan, UTBK SBMPTN 2020 diundur, dan pelaksanaan SNMPTN masih dalam pengkajian.(La ode Anhusadar, 2020)

Penyesuaian kebijakan pendidikan di masa pandemik corona ini pun mempengaruhi kebijakan pada perguruan tinggi keagamaan. Ini dapat terlihat pada Surat Edaran Nomor: 657/03/2020 Tentang Upaya Pencegahan Penyebaran Covid-19 (Corona) di lingkungan Perguruan Tinggi Keagamaan Islam yang berbunyi pimpinan PTKI melakukan pengalihan, Perkuliahan tatap muka menjadi pembelajaran jarak jauh mulai 16-29 Maret 2020 dan untuk selanjutnya akan dilakukan evaluasi. Melihat kondisi pandemic corona di Indonesia belum memperlihatkan penurunan angka pasien positif, kemudian Surat Edaran Nomor 697/03/2020 Tentang Perubahan Atas Surat Edaran Direktur Jenderal Pendidikan Islam Nomor 657/03/2020 Tentang Upaya Pencegahan Penyebaran Covid-19 (Corona) Di lingkungan Perguruan Tinggi Keagamaan Islam yang berbunyi proses perkuliahan hingga akhir semester genap tahun akademik 2019/2020 pada setiap perguruan tinggi 
4136 Pendidikan Masa Pandemik Covid 19: Implementasi Konsep Tri Pusat Pendidikan Ki Hajar Dewantara - Muhlil Musolin, Khoirun Nisa'

DOI: https://doi.org/10.31004/edukatif.v3i6.1316

keagamaan Islam baik negeri maupun swasta sepenuhnya di lakukan dalam jaringan (online).(La ode Anhusadar, 2020)

Bukan hanya perguruan tinggi saja namun semua sekolah dari tingkat TK, SD, SMP dan SMA merujuk pada Surat Edaran Mendikbud Nomor 3 Tahun 2020 tentang Pencegahan COVID-19 pada Satuan Pendidikan, dan Nomor 36962/MPK.A/HK/2020, maka kegiatan belajar mengajar pun dilakukan secara daring dalam rangka pencegahan penyebaran Corona Virus Disease (COVID-19).

Hal ini tentu menjadi fenomena baru dalam sejarah yang belum pernah dilaksanakan sebelumnya.Pembelajaran secara daring menjadi tantangan bagi semua pihak yaitu bagi siswa itu sendiri, bagi pendidik, bagi orang tua dan bagi lingkungan mahasiswa atau siswa tinggal.Momentum pandemic covid 19 ini dapat diambil hikmahnya yaitu dengan menjadikannya sebagai media mengimplementasikan konsep trilogi pusat pendidikan ki Hajar Dewantara. Oleh karena itu penelitian ini akan membahas tentang implementasi konsep tripusat pendidikan ki Hajar dewantara di masa pandemic covid 19.

\section{METODE PENELITIAN}

Penelitian ini menggunakan jenis penelitian kepustakaan (libraryresearch). Penelitian kepustakaan yakni penelitian yang menggunakan cara untuk mendapatkan data informasi dengan menempatkan fasilitas yang ada di perpus, seperti buku, majalah, dokumen, catatan kisah-kisah sejarah.(Sholeh, 2005)Sasaran penelitian kepustakaan adalah ingin menemukan berbagai teori,hukum, dalil, prinsip, pendapat, gagasan dan lain-lain yang dapat dipakai untuk menganalis dan memecahkan masalah yang diteliti.(DD., 2008)Sumber data penelitian ini adalah literatur ilmiah berupa buku-buku akademik, regulasi Pendidikan terbaru, laporan penelitian ilmiah, jurnal dan proseding, serta laporan resmi dari lembaga pendidikan.

Teknik pengumpulan data dilakukan dengan cara studi dokumentasi dan triangulasi. Studi dokumentasi yang dilengkapi dengan studi pustaka guna mendapatkan teori-teori, konsep-konsep sebagai bahan pembanding, penguat ataupun penolak terhadap temuan penelitian untuk kemudian ditarikkesimpulan.(Sadiah, 2012). Triangulasi bukan untuk mencari kebenaran tentang beberapa fenomena, tetapi lebih pada peningkatan pemahaman peneliti terhadap apa yang telah dikemukakan. Dalam penelitian ini digunakan cara triangulasi sumber, yaitu dengan menggalikebenaran satu atau beberapa informasi melalui beberapa sumber.(Gunawan, 2013)

Analisis data penelitian ini dilakukan dengan mengorganisasikan data, menjabarkan ke dalam unit-unit, melakukan sintesa, menyususn kedalam pola, memilih mana yang penting dan yang akan dipelajari, dan membuat kesimpulan yang dapat diceritakan kepada orang lain.(Sugiyono, 2007). Teknik analisis data dilakukan analisis konten yakni menggunakan kajian kualitatif dengan ranah konseptual. Mula-mula kata-kata dikumpulkan ke dalam elemen referensi yang telah umum sehingga mudah membangun konsep. Konsep tersebut diharapkan mewadahi isi atau pesan karya secara komprehensif.(Endraswara, 2011)Alur yang digunakan dalam analisis data yakni reduksi data, display data, dan penarikan kesimpulan.

\section{HASIL DAN PEMBAHASAN}

\section{Biografi Ki Hajar Dewantara}

Ki Hadjar Dewantara yang sebelumnya bernama Raden Mas Suwardi Suryaningrat, lahir di Yogyakarta pada tanggal 2 Mei 1889.(Hasbullah, 2013)Raden Mas Suwardi Suryaningrat kemudian berganti nama di usianya yang ke 39 tahun, ia berganti nama menjadi Ki Hadjar Dewantara. Lingkungan hidup pada masa Ki Hajar Dewantara kecil sangat besar pengaruhnya terhadap jiwanya yang sangat peka terhadap kesenian dan nilai-nilai kultur maupun religius.(Hariyadi, 1989)Dialah pendiri Perguruan Tinggi Nasional Taman Siswa yang didirikan pada 3 Juli 1922.(Moh.Yamin, 2008)

Suwardi berasal dari lingkungan keluarga Kadipaten Pakualaman, putra dari GPH Soerjaningrat, dan cucu dari Pakualam III.Selain mendapat pendidikan di lingkungan Istana Paku Alam, Ki.Hajar Dewantara 
4137 Pendidikan Masa Pandemik Covid 19: Implementasi Konsep Tri Pusat Pendidikan Ki Hajar Dewantara - Muhlil Musolin, Khoirun Nisa'

DOI: https://doi.org/10.31004/edukatif.v3i6.1316

juga mendapatkan pendidikan agama dari pesantren Kalasan di bawah asuhan KH.Abdurahman.(Rahardjo, 2009)Setelah itu tersebut, Ki Hadjar Dewantara juga mendapat pendidikan formal antara lain:ELS (Europeesche Legere School) Belanda III. Kweek School (Sekolah Guru) di Yogyakarta.STOVIA (School Tot Opvoeding Van Indische Artsen) yaitu sekolah kedokteran yang berada di Jakarta.Pendidikan di STOVIA ini tak dapat diselesaikannya, karena Ki Hadjar Dewantara sakit selama 4 bulan.(Yanuarti, 2017) Kemudian ia bekerja sebagai penulis dan wartawan dibeberapa surat kabar, antara lain, Sediotomo, Midden Java, De Expres, Oetoesan Hindia, Kaoem Moeda, Tjahaja Timoer, dan Poesara. Pada masanya, ia tergolong penulis handal. Tulisan-tulisannya komunikatif dan tajam dengan semangat anticolonial.

Selain ulet sebagai seorang wartawan muda, ia juga aktif dalam organisasi social dan politik. Sejak berdirinya Boedi Oetomo (BO) tahun 1908, ia aktif di seksi propaganda untuk menyosialisasikan dan menggugah kesadaran masyarakat Indonesia (terutama Jawa) pada waktu itu mengenai pentingnya persatuan dan kesatuan dalam berbangsa dan bernegara. Konggres pertama BO di Yogyakarta juga diorganisasi olehnya.Soewardi muda juga menjadi anggota organisasi Insulinde, suatu organisasi multietnik yang didominasi kaum Indo yang memperjuangkan pemerintahan sendiri di Hindia Belanda, atas pengaruh Ernest Douwes Dekker (DD).Ketika kemudian DD mendirikan Indische Partij, Soewardi diajaknya juga.(Suwahyu, 2018)

Tanggal 3 Juli 1922, Ki Hadjar Dewantara kemudian mendirikan Taman Siswa yang awalnya bernama National Onderwijs Instituut.Setelah berdiri Taman Siswa mendapat banyak tekanan dari pihak pemerintah kolonial Belanda pada waktu itu.Seperti pada tahun 1934-1936, adanya kebijakan politik dari pemerintah Belanda yaitu Orderwijsverbod (larangan mengajar). Jumlah guru yang menjadi korban akibat keluarnya surat itu berjumlah 60 orang, bahkan ada cabang Taman Siswa yag ditutup selama satu tahun.(Moh.Yamin, 2008) Pada masa sebelum kemerdekaan, Ki Hadjar Dewantara pindah ke Jakarta karena diangkat menjadi salah satu pimpinan Putera (Pusat Tenaga Rakyat) bersama dengan Ir. Soekarno, Bung Hatta, dan Kiai H. Mas Mansoer. Keempat tokoh tersebut disebut Empat Serangkai.(Suwahyu, 2018)

Tahun 1944, Ki Hadjar Dewantara diangkat menjadi Naimubu Bunkyoku Sanjo (Kepala Kebudayaan). Pasca kemerdekaan, ia menjadi menteri PPK, anggota dan wakil ketua Dewan Pertimbangan Agung, anggota Parlemen, dan mendapat gelar doktor honoris causa (doktor kehormatan) dalam ilmu kebudayaan dari UGM tanggal 26 Desember 1956. Ki Hadjar Dewantara meninggal di Yogyakarta tanggal 26 April 1959.(Moh.Yamin, 2008)

\section{Tripusat Pendidikan}

Melalui pembaharuan terhadap model pawiyetan (pesantren) yang diproyeksikan sebagai sistem nasional dan berorientasi pada nilai budaya, kebangsaan, dan kerakyatan, lahirlah Taman Siswa.Dalam model ini, mencakup tiga wilayah pendidikan yang dikenal dengan "Tripusat Pendidikan". Menurut Ki Hadjar Dewantara, seorang guru ibarat sumur yang jernih (sumber keilmuan yang harus ditimba), sedangkan seorang siswa ibarat musafir yang kehausan. Oleh karena itu, bukan guru yang harus datang ke sekolah-sekolah mendidik siswa, melainkan para siswa yang harus mendatangi rumah guru, untuk menimba ilmu dan pengalaman darinya.(Thobroni \& Mustofa, 2013)

Tripusat pendidikan menurut Ki Hadjar Dewantara ialah bahwa di dalam hidupnya anak-anak ada tiga tempat pergaulan yang menjadi pusat pendidikan yang amat penting baginya, yaitu: alam keluarga, alam perguruan, dan alam pergerakan pemuda.(Dewantara, 2004) Hal ini yang kemudian dikenal dewasa ini dengan nama tripusat pendidikan atau trilogi pendidikan.Trilogi pendidikan yang dimaksud oleh Ki Hadjar Dewantara adalah bagaimana peran keluarga, sekolah dan masyarakat mampu menjadi motor pembentukan karakter dan mentalitas anak.(Moh.Yamin, 2008)

Tiga unsur di atas memiliki tanggung jawab yang berbeda dalam membentuk karakter yang ada pada diri seorang anak.(Moh.Yamin, 2008)Pertama, pendidikan informal atau pendidikan keluarga sangatlah penting untuk membentuk kepribadian anak. Karena menurut Ki Hadjar Dewantara bahwa rasa cinta, rasa 
4138 Pendidikan Masa Pandemik Covid 19: Implementasi Konsep Tri Pusat Pendidikan Ki Hajar Dewantara - Muhlil Musolin, Khoirun Nisa'

DOI: https://doi.org/10.31004/edukatif.v3i6.1316

bersatu, dan lain-lain perasaan dan keadaan jiwa yang pada umumnya sangat bermanfaat terhadap berlangsungnya pendidikan, terutama pada pendidikan karakter yaitu terdapat pada hidup dalam keluarga yang sifatnya kuat dan murni yang tidak akan sama dengan pendidikan yang ada di tempat lain.(Dewantara, 2004)

Sehingga pendidikan dalam keluarga harusnya mampu menjadi pondasi yang kuat yang ada dalam diri anak dalam kehidupan yang akan dilaluinya kelak. Menurut Hadi Sutrisno dalam Moh.Yamin, "membina anak merupakan salah satu tugas yang menggereja.Pendidikan di dalam keluarga menjadi suatu hal yang penting dan pokok, sementara di sekolah pendidikan hanya sebagai tambahan karena pendidikan di sekolah hanya berlangsung beberapa jam saja.(Moh.Yamin, 2008)Sehingga, peran keluarga begitu vital dalam perkembangan anak.Di dalam ajaran Islam, terdapat banyak hadis-hadis Nabi tentang pentingnya memberikan pendidikan akhlak bagi anak dalam kelurga.Peran anggota keluarga sangat dibutuhkan, terutama ayah dan ibu dalam membantu tumbuh kembang anak ke arah yang positif.

Kedua, alam perguruan merupakan pusat perguruan yang teristimewa berkewajiban mengusahakan kecerdasan pikiran (perkembangan intelektual) beserta pemberian ilmu pengetahuan (balai-wiyata).Ketiga, alam pemuda atau alam kemasyarakatan merupakan kancah pemuda untuk beraktivitas dan beraktualisasi diri mengembangkan potensi dirinya. Beberapa hal yang menarik tentang keterangan Ki Hadjar Dewantara tentang Tripusat Pendidikan yaitu:

1. Tujuan pendidikan tidak mungkin tercapai melalui satu jalur saja;

2. Ketiga pusat pendidikan tersebut harus berhubungan seakrab-akrabnya;

3. Bahwa alam keluarga tetap merupakan pusat pendidikan yang terpenting dan memberikan pendidikan budi pekerti, agama dan laku social;

4. Bahwa perguruan sebagai balai wiyata yang memberikan ilmu pengetahuan dan pendidikan keterampilan;

5. Bahwa alam pemuda (yang sekarang diperluas menjadi lingkungan/ alam kemasyarakatan) sebagai tempat sang anak berlatih membentuk watak atau karakter dan kepribadiannya;

6. Dasar pemikiran Ki Hadjar Dewantara ialah usaha untuk menghidupkan, menambah dan memberikan perasaan kesosialan sang anak.

Pandangan yang demikian ini, membuat Ki Hadjar Dewantara tidak memandang perguruan atau sekolah sebagai lembaga yang memiliki orientasi mutlak dalam proses pembentukan karakter anak. Justru beliau memandang pendidikan sebagai suatu proses yang melibatkan unsur-unsur lain di luar sekolah.

Tiap-tiap pusat harus mengetahui kewajiban masing-masing, atau kewajibannya sendiri- sendiri, dan mengakui hak pusatpusat lainnya yaitu: alam keluarga untuk mendidik budi pekerti dan laku sosial. Alam sekolah sebagai balai wiyata bertugas mencerdaskan cipta, rasa, dan karsa secara seimbang.Sedangkan alam pemuda atau masyarakat untuk melakukan penguasaan diri dalam pembentukan watak atau karakter.(Suwahyu, 2018)

\section{Implementasi Konsep Tripusat Pendidikan Ki Hajar Dewantara pada Pendidikan Masa Pandemik Covid 19}

Dengan mewabahnya Virus Coroana atau Pandemik Covid 19 Pemerintah Indonesia kemudian menerbitkan beberapa aturan diantaranya Peraturan Pemerintah Nomor 21 Tahun 2020 tentang Pembatasan Sosial Berskala Besar Dalam Rangka Percepatan Penanganan Corona Virus Disease 2019 (Covid-19) ("PP No. 21/2020"). Peraturan Pembatasan Sosial Berskala Besar paling ini diantaranya mengatur tentang peliburan sekolah. Kemudian Kemeterian Pendidikan menerbitkan Surat Edaran Mendikbud Nomor 3 Tahun 2020 tentang Pencegahan COVID-19 pada Satuan Pendidikan, dan Nomor 36962/MPK.A/HK/2020, maka kegiatan belajar mengajar pun dilakukan secara daring. Pembelajaran daring artinya mahasiswa atau siswa tidak berangkat kekampus atau sekolah akan tetapi mahasiswa atau siswa belajar dari rumah. Mahasiswa atau siswa belajar di rumah sehingga mengharuskan adanya keterlibaan beberapa pihak yaitu orang tua, Pendidik (dosen 
4139 Pendidikan Masa Pandemik Covid 19: Implementasi Konsep Tri Pusat Pendidikan Ki Hajar Dewantara - Muhlil Musolin, Khoirun Nisa'

DOI: https://doi.org/10.31004/edukatif.v3i6.1316

dan guru) dan lingkungan.Dengan demikian Implementasi dari konsep tri pusat pendidikan Ki Hajar Dewantara dalam pendidikan masa pandemic covid 19 dapat kita lihat dari peran masing masing pihak.

\section{Peran Keluarga}

Kebijakan pemerintah dengan meliburkan sekolah dimasa pandemic covid 19 menyebabkan para mahasiswa dan siswa beraktifitas dalam rumah.Hal ini menjadi kesempatan keluarga untuk berperan aktif dalam mengontrol, mengawasi, membimbing dan mengarahkan mahasiswa dan siswa.

Menurut Undang-Undang Nomor 20 Tahun 2003 bahwa keluarga merupakan salah satu penanggung jawab pendidikan, disamping masyarakat dan pemerintah.Keberadaan orang tua sebagai penanggung jawab utama dalam menanamkan nilai-nilai paling dasar sebelum anak masuk dalam komunitas berikutnya, karena keluarga dapat dipandang sebagai lembaga pendidikan yang sangat vital bagi kelangsungan pendidikan generasi muda maupun bagi pembinaan bangsa pada umumnya.(Gordillo Montaño et al., 2003)

Keluarga menurut Depkes (1988) dalam Setiawati (2008) adalah unit terkecil dari masyarakat yang terdiri atas kepala keluarga dan beberapa orang yang terkumpul dan tinggal di suatu tempat dibawah suatu atap dalam keadaan saling ketergantungan.Keluarga yang harmonis selalu berupaya untuk menjalankan fungsinya dengan semestinya. Fungsi ini mengacu pada interaksi anggota keluarga terutama pada kualitas hubungan dan interaksi mereka.(Wong, 2009)

Menurut Friedman (1998) ada 5 fungsi keluarga, yaitu fungsi afektif (affective function), fungsi sosialisasi dan penempatan sosial (socialization and social placement function), fungsi reproduksi (reproductive function), fungsi ekonomi (economic function), fungsi perawatan dan pemeliharaan kesehatan (health care function).(Setyaningrum, Fitria, \& Taty, 2012)

Sebagai salah satu pusat pendidikan, keluarga mempunyai tugas yang sangat fundamental dalam upaya mempersiapkan anak bagi peranannya pada masa yang akan datang. Dalam lingkungankeluarga sudah mulai ditanamkan dasar-dasar perilaku, sikap hidup dan kebiasaan lainnya.Dalam lingkungan keluarga anak-anak dididik mulai dari belajar, berjalan, bersikap, berperilaku keagamaannyadan pengetahuan serta kemampuan lainnya. Dengan demikian pendidikan dalam keluaga akan membimbing anak dalam kecerdasan intelektual, emosional dan spiritual. Karena dalam keluarga anak dididik untuk berpikirkritis dengan cara selalu berdialog kepada anak untuk memecahkan masalah dan dalam keluarga anak pun dididik untuk dapat menghargai dan menghormati orang lain seperti ketika sedang berbicara anak dilarang untuk memotong pembicaraannya dan ketika libur sekolah anak membantu pekerjaan nya di rumah.(Rahmah, 2016)

Pada dasarnya kunci pendidikan dalam rumah tangga terletak pada pendidikan rohani, dalam arti pendidikan kalbu (agama), karena pendidikan agamalah yang berperan sangat besar dalam membentuk kepribadian dan pandangan hidup seseorang, ada dua arah mengenai kegunaan pendidikan agama dalam rumah tangga, yaitu:

1. Penanaman nilai dalam arti pandangan hidup yang kelak mewarnai perkembangan jasmani dan akalnya;

2. Penanaman sikap yang kelak menjadi basis dalam menghargai guru dan pengetahuan di sekolah.(TAFSIR, 2007)

Dalam hal ini orangtua memiliki fungsi utama di dalam kehidupan anak dengan cara memberikan bimbingan, arahan, petunjuk dengan sebaik mungkin, hal ini dikarenakan baik buruknya kehidupan anak di masa mendatang akan banyak ditentukan dari berhasil tidaknya orangtua dalam menjalankan fungsinya.(Makhmudah, 2018)

Dengan demikian Pendidikan di masa pandemic covid 19 ini menjadi wahana dalam mengimplementasikan konsep tri pusat pendidikan Ki Hajar Dewantara dengan memaksimalkan fungsi keluarga sebagai bagian dari lembaga pendidikan dimana keluarga terutama orang tua menanamkan dasardasar perilaku, sikap hidup dan kebiasaan yang baik serta pengetahuan tentang agama pada anaknya. Oleh karena itu fungsi pendidikan dalam keluaga yaitu membimbing anak dalam kecerdasan intelektual, emosional dan spiritual dimasa pademik covid 19 dapat berjalan dengan baik.Sebagaimana dalam konsep tri pusat 
4140 Pendidikan Masa Pandemik Covid 19: Implementasi Konsep Tri Pusat Pendidikan Ki Hajar Dewantara - Muhlil Musolin, Khoirun Nisa'

DOI: https://doi.org/10.31004/edukatif.v3i6.1316

pendidikan Ki Hajar Dewantara bahwa alam keluarga untuk mendidik budi pekerti dan laku sosial juga dapat tercapai dengan maksimal.

\section{Peran Sekolah}

Sekolah adalah tempat kegiatan dan proses pendidikan berlangsung.(Sefriani \& Sepriana, 2020) Yusuf mengatakan bahwa sekolah juga dapat merupakan lembaga pendidikan formal yang berjalan sistematis melaksanakan program bimbingan, pengajaran, dan latihan dalam rangka membantu siswa agar mampu mengembangkan potensinya baik yang menyangkut aspek moral, spiritual, intelektual, emosional maupun sosial.(Gana \& Priyanto Anang, 2017)Tu'u berpendapat di sekolah diadakan kegiatan pendidikan, pembelajaran dan latihan oleh pendidik (guru) dalam pengawasan Kepala Sekolah sebagai pimpinan tertinggi Sekolah.(Gana \& Priyanto Anang, 2017)

Dengan demikian yang paling berperan dalam pendidikan disekolah adalah seorang guru atau pendidik.Pendidik dalam Undang-undang Sisdiknas No. 20 tahun 2003 Pasal 1 No 6 didefinisikan dengantenaga kependidikan yang berkualifikasi sebagai guru, dosen, konselor, tutor, instruktur,fasilitator, dan sebutan lain yang sesuai dengan kekhususannya, serta berpartisipasi dalammenyelenggarakan pendidikan.(Gordillo Montaño et al., 2003) Undang-Undang Nomor 20 Tahun 2003, Bab XI Pasal 39Ayat 2 menyatakan bahwa Pendidik merupakan tenaga profesional yang bertugas merencanakan dan melaksanakan proses pembelajaran, menilai hasil pembelajaran, melakukan pembimbingan dan pelatihan, serta melakukan penelitian dan pengabdian kepada masyarakat, terutama bagi pendidik pada perguruan tinggi.(Gordillo Montaño et al., 2003)

Dalam kamus Besar Bahasa Indonersia, guru dipahami sebagai orang yang kerjanya mengajar perguruan sekolah, gedung tempat belajar, perguruan tinggi sekolah tinggi dan universitas.(KBBI, 2016) Oleh karena itu pendidikatau guru adalah suatu kedudukan yang melekat pada diri orang tertentu dan dengan kedudukan itu padanya terdapat tanggung jawab untuk mengajar dan membelajarkan peserta didik yang ia hadapi.(Sefriani \& Sepriana, 2020) Guru pun merupakan suatu jabatan yang memerlukan keahlian khusus sebagai guru dan tidak dapat dilakukan sembarang orang diluar bidang pendidikan.(Juhji, 2016)

Beberapa hal yang menjadi tugas pendidik professional adalah sebagai berikut:

1. Pendidik sebagai orang tua;

2. Pendidik sebagai pewaris ilmu Nabi;

3. Pendidik sebagai penunujuk jalan dan pembimbing keagamaan;

4. Pendidik sebagai sentral figure;

5. Pendidik sebagai motivator;

6. Pendidik sebagai seorang yang memahami tingkat perkembangan intelektual;

7. Pendidik sebagai teladan.(Andriyani, 2015)

Pendidik yang seringkali berfungsi sebagai expert, resource person, fasilitator, instructor, model, mentor, co-learner, reflective practicioner, dan researcher.Penjelasan singkat dari peran pendidik tersebut adalah sebagai berikut:

1. Expert. Seorang pendidik tentu ahli pada berbagai bidang, minimal ahli pada mata pelajaran atau kuliah yang ia ampu. Pendidik berperan untuk menularkan keahliannya kepada subyek didiknya;

2. Resource Person. Seorang pendidik berperan sebagai sumber rujukan bagi subyek didiknya;

3. Fasilitator. Seorang pendidik berperan sebagai fasilitator yang berkewajiban menciptakan kondisi subyek didik dalam proses pembelajaran untuk mencapai kompetensi yang telah ditentukan;

4. Instructor. Seorang pendidik tentu mampu berperan sebagai instruktur yang memberiinstruksi/arahan kepada subyek didiknya supaya dapat mencapai kompetensi yangdiharapkan;

5. Model. Sering kali pendidik berperan sebagai model ideal dari subyek didiknya, terutama dari segi perilaku (karakter), penegakan sistem nilai, intelektualitas, dan profesinya; 
4141 Pendidikan Masa Pandemik Covid 19: Implementasi Konsep Tri Pusat Pendidikan Ki Hajar Dewantara - Muhlil Musolin, Khoirun Nisa'

DOI: https://doi.org/10.31004/edukatif.v3i6.1316

6. Mentor. Pendidik berperan memberi nasehat kepada subyek didiknya terutama yang terkait dengan pembelajaran;

7. Co-Learner. Seringkali pendidik berperan sebagai mitra subyek didik mulai dari merencanakan pembelajaran, proses pembelajaran, dan bahkan sampai evaluasinya;

8. Reflective Practicioner. Pendidik berperan sebagai praktisi reflektif terutama menguji kompetensi subyek didiknya dari segi sikap dan perilakunya;

9. Reseacher. Pendidik berperan sebagai peneliti dalam pembelajaran melalui observasi,memformulasikan hipotesis, mengembangkan suatu teori dan mempraktekkannya.

Masa pandemic covid 19 menyebabkan semua lembaga pendidikan dari TK, SD, SMP dan SMA serta Perguruan Tinggi melaksanakan pembelajaran secara daring sehingga guru, dosen, siswa dan mahasiwa dapat melakukan pembelajaran hanya dengan mengadalakan koneksi internet dan mereka tidak membutuhkan ruangan tempat berkumpul untuk melakukan proses pembelajaran.

Begitu banyak aplikasi yang bisa digunakan untuk membantu proses pembelajaran online, Nextren telah merangkum 3 aplikasi yang bisa kamu gunakan untuk tetap bisa berkuliah dari rumah:

\section{Zoom Cloud Meeting;}

2. Skype;

3. WhatsApp.(La ode Anhusadar, 2020)

Dengan melaksanakan pendidikan secara online maka sekolah melalui para pendidik (Dosen dan Guru) hanya bisaberfungsi sebagai expert yang berperan untuk menularkan keahliannya kepada subyek didiknya, resource Person yaitu sebagai sumber rujukan bagi peserta didik, fasilitator yang berkewajiban menciptakan kondisi subyek didik dalam proses pembelajaran untuk mencapai kompetensi yang telah ditentukan, instruktor yang memberi instruksi/arahan kepada subyek didiknya supaya dapat mencapai kompetensi yang diharapkan dan mentor yang berperan memberi nasehat kepada subyek didiknya terutama yang terkait dengan pembelajaran.

Adapun peran Pendidik sebagai Model.yang berperan sebagai model ideal dari subyek didiknya, terutama dari segi perilaku (karakter), penegakan sistem nilai, intelektualitas, dan profesinya, Co-Learner yangberperan sebagai mitra subyek didik mulai dari merencanakan pembelajaran, proses pembelajaran, dan bahkan sampai evaluasinya. reflective Practicioner yangberperan sebagai praktisi reflektif terutama menguji kompetensi subyek didiknya dari segi sikap dan perilakunya dan researcher yang berperan sebagai peneliti dalam pembelajaran melalui observasi, memformulasikan hipotesis, mengembangkan suatu teori dan mempraktekkannya dimasa pandemic covid 19 tidak bisa terlaksana.

Dan tugas pendidik yang profisoal yaitu sebagai orang tua, pewaris ilmu Nabi, penunujuk jalan dan pembimbing keagamaan, sentral figure, motivator, seorangyang memahami tingkat perkembangan intelektual dan sebagai teladan tidak bisa berjalan dengan maksimal. Oleh karena itu konsep tri pusat pendidikan Ki Hajar Dewantara bahwa sekolah sebagai balai wiyata bertugas mencerdaskan cipta, rasa, dan karsa secara seimbang dalam pendidikan masa pandemic covid 19 tidak terwujud dengan baik.

\section{Peran Masyarakat}

Masyarakat merupakan istilah yang sangat lazim digunakan untuk menyebut suatu kesatuan-kesatuan manusia yang berasal dari bahasa Arab yaitu Syaraka yang berarti ikut serta, berpartisipasi, yang kemudian mengalami perubahan dalam bahasa Indonesia menjadi masyarakat. Masyarakat adalah suatu kesatuan manusia yang saling berinteraksi menurut suatu sistem adat-istiadat tertentu yang bersifat kontinu dan saling terikat oleh suatu rasa dan identitas yang sama dalam dirinya.(Koentjaraningra, 2015)

Peran masyarakat dalam pendidikan tercantum dalam Undang-Undang Nomor 20 Tahun 2003 Pasal 8 dan 9 yang menyatakan bahwa masyarakat berhak berperan serta dalam perencanaan, pelaksanaan, pengawasan dan evaluasi program kerja pendidikan serta berkewajiban memberikan dukungan sumber daya dalam penyelenggaraan pendidikan.(Gordillo Montaño et al., 2003) 
Masyarakat berperan sangat penting pada perkembangan pendidikan anak.Oleh karenanya masyarakat hendaknya ikut serta berpartisipasi dalam kegiatan pendidikan anak baik langsung atau tidak langsung.Karena lingkungan dalam keluarga, dan sekolah serta masyarakat sangat memiliki keterikatan.(Sada, 2017)

Masyarakat merupakan lingkungan ketiga setelah keluarga dan sekolah. Masyarakat diartikan sebagai sekumpulan orang yang menempati suatu daerah, diikat oleh pengalaman-pengalaman yang sama, memiliki sejumlah persesuaian dan sadar akan kesatuannya, serta dapat bertindak bersama untuk mencukupi krisis kehidupannya.(Barnadib, 1986)

Masyarakat sebagai lingkungan/lembaga pendidikan ketiga memiliki pengaruh besar terhadap perkembangan pribadi seseorang.Dalam hal ini, masyarakat mempunyai peranan penting dalam upaya ikut serta menyelenggarakan pendidikan, membantu pengadaan tenaga, biaya, sarana prasarana dan menyediakan lapangan kerja.

Karenanya, partisipasi masyarakat dalam usaha mencerdaskan kehidupan bangsa sangat diharapkan. Selanjutnya, pendidikan dalam masyarakat memiliki ciri-ciri sebagai berikut :

1. Diselenggarakan dengan sengaja di luar sekolah;

2. Peserta umumnya mereka yang tidak bersekolah atau drop out;

3. Tidak mengenal jenjang dan program pendidikan untuk jangka waktu pendek;

4. Peserta tidak perlu homogen;

5. Ada waktu belajar dan metode formal, serta evaluasi yang sistematis;

6. Isi pendidikan bersifat praktis dan khusus;

7. Keterampilan kerja sangat ditekankan sebagai jawaban terhadap kebutuhan meningkatkan taraf hidup.(Tanlain \& Dkk, 1989)

Selanjutnya, ada beberapa istilah yang diberikan kepada lembaga pendidikan masyarakat sebagai jalur pendidikan luar sekolah :

1. Pendidikan sosial, yaitu proses yang diusahakan dengan sengaja di dalam masyarakat untuk mendidik individu dan lingkungan sosial, supaya bebas dan bertanggung jawab;

2. Pendidikan masyarakat, merupakan pendidikan yang ditujukan kepada orang dewasa, termasuk pemuda di luar batas umur tertinggi, kewajiban belajar dan dilakukan di luar lingkungan dan sistem persekolahan resmi;

3. Pendidikan rakyat adalah tindakan-tindakan atau pengaruh yang terkadang mengenai seluruh rakyat;

4. Pendidikan Luar Sekolah adalah pendidikan yang dilakukan di luar sistem persekolahan biasa;

5. Mass Education adalah pendidikan yang ditujukan kepada orang dewasa di luar lingkungan sekolah;

6. Adult Education adalah pendidikan untuk orang dewasa yang mengambil umur batas tertinggi dari masa kewajiban belajar;

7. Extension Education adalah suatu bentuk dari adult education, yaitu pendidikan yang diselenggarakan di luar sekolah biasa, yang khusus dikelola oleh Perguruan Tinggi untuk menyahuti hasrat masyarakat yang ingin masuk dunia Universitas, misalnya Universitas Terbuka;

8. Fundamental Education ialah pendidikan yang bertujuan membantu masyarakat untuk mencapai kemajuan sosial ekonomi, agar mereka dapat menempati posisi yang layak.(Gazali, 2013)

Oleh karena itu, partisipasi masyarakat dalam usaha mencerdaskan kehidupan bangsa sangat diharapkan.Masyarakat sebagai lembaga pendidikan ketiga menjadi ajang pengoptimalan perkembangan dan aktualisasi diri setiap individu.

Pada masa pandemic covid 19 ini peran serta masyarakat untuk turut andil dalam pendidikan mahasiswa dan siswa di lingkungannya sangat dibutuhkan walaupun ada aturan semua orang untuk tetap tinggal dirumah.Adanya aturan tetap tinggal dirumah tidak menutup kemungkinan terjadinya pergaulan semisal adanya kematian, shalat berjamaah, shalat ied dan belanja di warung.Peran serta masyarakat dalam pendidikan dapat berupa kepatuhan mengikuti protoker kesehatan dan aturan pemerintah. Sehingga peran pemuda atau 
4143 Pendidikan Masa Pandemik Covid 19: Implementasi Konsep Tri Pusat Pendidikan Ki Hajar Dewantara - Muhlil Musolin, Khoirun Nisa'

DOI: https://doi.org/10.31004/edukatif.v3i6.1316

masyarakat untuk melakukan penguasaan diri dalam pembentukan watak atau karakter dalam konsep tri pusat pendidikan Ki Hajar Dewantara pada masa pandemic covid 19dapat terlaksana dengan baik.

\section{KESIMPULAN}

Implementasi dari konsep tri pusat pendidikan Ki Hajar Dewantara dalam pendidikan masa pandemic covid 19 dapat kita lihat dari peran masing masing pihak yaitu: 1) Peran Keluarga Pendidikan di masa pandemic covid 19 menyebabkan mahasiswa dan siswa lebih banyak berada dirumah seingga implementasi konsep tri pusat pendidikan Ki Hajar Dewantara bahwa alam keluarga untuk mendidik budi pekerti dan laku sosial dimana keluarga terutama orang tua menanamkan dasar-dasar perilaku, sikap hidup dan kebiasaan yang baik serta pengetahuan tentang agama pada anaknya dan membimbing anak dalam kecerdasan intelektual, emosional dan spiritual dapat berjalan dengan baik. 2) Peran Sekolah, masa pandemic covid 19 sekolah melaksanakan pendidikan secara online maka sekolah yang dalam konsep tri pusat pendidikan Ki Hajar Dewantara sebagai balai wiyata bertugas mencerdaskan cipta, rasa, dan karsa secara seimbang dalam pendidikan masa pandemic covid 19 tidak terwujud dengan baik. 3) Peran Masyarakat pada masa pandemic covid 19 dalam pendidikan dapat berupa kepatuhan mengikuti protoker kesehatan dan aturan pemerintah.Sehingga peran pemuda atau masyarakat untuk melakukan penguasaan diri dalam pembentukan watak atau karakter dalam konsep tri pusat pendidikan Ki Hajar Dewantara pada masa pandemic covid 19 dapat terlaksana dengan baik.

\section{DAFTAR PUSTAKA}

Andriyani, I. N. (2015). Peran Pendidik dalam Pendidikan Islam Berkarakter. Jurnal Komunikasi dan Pendidikan Islam, 4(1), 137-159.

Barnadib, S. I. (1986). Pengantar Ilmu Pendidikan Sistematis. Yogyakarta: FIP IKIP.

DD., S. (2008). Panduan Penulisan Skripsi. Yogyakarta: Jurusan Pendidikan.

Dewantara, K. H. (2004). Pendidikan. Yogyakarta: Majelis Luhur Persatuan Taman Siswa.

Endraswara, S. (2011). Metodologi Penelitian Sastra. Yogyakarta: Tim Redaksi CAPS.

Gana, F. E., \& Priyanto Anang. (2017). Peranan Sekolah dalam Menanggulangi Perilaku Menyimpang Siswa di Sekolah Menengah Pertama Negeri 13 Kota Magelang. Pendidikan Kewarganegaraan dan Hukum, (3), 629-642.

Gazali, M. (2013). Optimalisasi Peran Lembaga Pendidikan untuk Mencerdaskan Bangsa. Al-Ta'dib, 6(1), 1689-1699. https://doi.org/10.1017/CBO9781107415324.004

Gordillo Montaño, M., González Galbarte, J., Guillermo, C., León, G., High, V., Osorio, C., ... Cristea, A. (2003). UU RI No 20 Tahun 2003 tentang Sistem Pendidikan Nasional. Futures. https://doi.org/10.35362/rie280958

Gunawan, I. (2013). Metode Penelitian Kualitatatif: Teori \& Praktik,. Jakarta: Bumi Aksara.

Hariyadi, K. (1989). Ki Hadjar Dewantara sebagai Pendidik, Budayawan, Pemimpin Rakyat dalam Buku Ki Hadjar Dewantara dalam Pandangan Para Cantrik dan Mentriknya. Yogyakarta: MLTS.

Hasbullah. (2013). Dasar-Dasar Ilmu Pendidikan. Jakarta: RajaGrafindo Persada.

Juhji. (2016). Guru, mendidik, mengajar, nilai, pembentukan kepribadian, panutan. Studia Didaktika, 10(1), $52-62$.

KBBI. (2016). Kamus Besar Bahasa Indonesia ( KBBI ). Kementerian Pendidikan dan Budaya.

Koentjaraningra. (2015). Pengantar Ilmu Antropologi. Jakarta: Rineka Cipta.

La ode Anhusadar. (2020). Persepsi Mahasiswa Piaud Terhadap Kuliah Online Di Masa Pandemi Covid 19. 
4144 Pendidikan Masa Pandemik Covid 19: Implementasi Konsep Tri Pusat Pendidikan Ki Hajar Dewantara - Muhlil Musolin, Khoirun Nisa'

DOI: https://doi.org/10.31004/edukatif.v3i6.1316

KINDERGARTEN: Journal of Islamic Early Childhood Education, 3(1), 44-58. https://doi.org/http://dx.doi.org/10.24014/kjiece.v3i1.9609

Makhmudah, S. (2018). Penguatan Peran Keluarga Dalam Pendidikan Anak. Martabat: Jurnal Perempuan dan Anak, 2(2). https://doi.org/10.21274/martabat.2018.2.2.269-286

Moh.Yamin. (2008). Menggugat Pendidikan Indonesia "Belajar dari Paulo Freire dan Ki Hadjar Dewantara. Yogyakarta: Ar-Ruzz Media.

Rahardjo, S. (2009). Biografi Singkat Ki. Hajar Dewantara, 1889-1959. Yogyakarta: Garasi.

Rahmah, S. (2016). Peran Keluarga Dalam Pendidikan Akhlak. Alhiwar Jurnal Ilmu dan Teknik Dakwah Vol., 04(07), 13-23.

Sada, H. J. (2017). ISLAM PENDAHULUAN Hakekat pembangunan nasional adalah pembangungan manusia Indonesia seutuhnya dan pembanguan seluruh masyarakat Indonesia . Landasan pembangunan nasional Indonesia adalah pancasila dengan berusaha untuk mewujudkan tujuan nasional yaitu me. $8(\mathrm{I}), 117-125$.

Sadiah, D. (2012). Metode Penelitian Dakwah Pendekatan Kualitatif dan Kuantitatif. 2015: Remaja Rosdakarya.

Sefriani, R., \& Sepriana, R. (2020). Pengembangan Media E-Learning Berbasis Schoology pada Pembelajaran Kurikulum Pendidikan Teknologi dan Kejuruan. EDUKATIF: JURNAL ILMU PENDIDIKAN, 2(1), 57. Diambil dari http://jurnal.globalhealthsciencegroup.com/index.php/JPPP/article/download/83/65\%0Ahttp://www.em base.com/search/results?subaction=viewrecord\&from=export\&id=L603546864\%5Cnhttp://dx.doi.org/1 0.1155/2015/420723\%0Ahttp://link.springer.com/10.1007/978-3-319-76887-

Setyaningrum, D. N., Fitria, N., \& Taty, H. (2012). Gambaran fungsi keluarga pada warga binaan remaja di rumah tahanan negara klas i bandung. Students e-Journal, 1(1), 1-16.

Sholeh, A. R. (2005). Pendidikan Agama dan Pengembangn untuk Bangsa. Jakarta: PT. Raja Grafindo Persada.

Sugiyono. (2007). Metode Penelitian Kuantitatif, Kualitatif, dan $R \&$ D. Bandung: Alfabeta.

Suwahyu, I. (2018). Pendidikan Karakter Dalam Konsep Pemikiran Pendidikan Ki Hajar Dewantara. INSANIA : Jurnal Pemikiran Alternatif Kependidikan, 23(2), 192-204. https://doi.org/10.24090/insania.v23i2.2290

TAFSIR, A. (2007). Ilmu Pendidikan Dalam Perspektif Islam. In PT Remaja Rosdakarya. https://doi.org/10.1002/bit.260460310

Tanlain, W., \& Dkk. (1989). Dasar-Dasar Ilmu pendidikan. Jakarta: Gramedia.

Thobroni, M., \& Mustofa, A. (2013). Belajar dan Pembelajaran "Pengembangan Wacana dan Praktik Pembelajaran dalam Pembangunan Nasional.” Yogyakarta: Ar-Ruzz Media.

Wong, D. L. (2009). BUKU AJAR Keperawatan Pediatrik (6 ed.). Jombang: Buku kedokteran EGC.

Yanuarti, E. (2017). Pemikiran Pendidikan Ki. Hajar Dewantara Dan Relevansinya Dengan Kurikulum 13. Jurnal Penelitian, 11(2), 237-266. https://doi.org/10.21043/jupe.v11i2.3489 